\title{
A Study on the Perceptions and Needs of e-Sports and e-Sports Stadiums
}

\author{
$\mathrm{Ho} \mathrm{Yoo}^{1}$ \\ ${ }^{1}$ Professor, Department of Sports and Leasure, Catholic Kwandong University, Korea, \\ yooho@cku.ac.kr
}

\begin{abstract}
The purpose of this study is to investigate on the experience and awareness of e-sports among university students majoring in sports and to identify the facility-related needs of e-sports stadiums. For this purpose, 74 students majoring in sports at a four-year university were surveyed. According to the survey, most students had experience in e-sports and thought that the prospects for e-sports were bright. On the other hand, the average of items related to general sports, willingness to take courses and the desire to engage in relevant professions was not high. In the case of correlation between perceptions of e-sports, there was a significant positive correlation, such as interest in e-sports, prospects, willingness to engage in relevant work, willingness to take relevant courses, and awareness of the connection between e-sports and general sports. In the case of the demand for the stadium for e-sports, the demand for the degree of visibility of the stadium from the seats and the size of the electronic signboard was the greatest, and the demand for sound facilities was generally high. Meanwhile, the demand for the time required to reach the stadium and the degree of traffic congestion was relatively low for other items.
\end{abstract}

Keywords: e-sports, Perception Stadium, University Students, Sports Major

\section{Introduction}

Recently, people's interest in leisure activities is increasing[1][2]. One of the new cultural trends in recent years is electronic sports ("e-sports"). Especially, it is receiving great attention from the younger generation, and the recent enthusiasm of e-sports in Korea is world-famous[3][4]. "Starting in 2004, the "Ongamenet SKY Pro League 2004" Round 1 Final attracted 100,000 spectators." will attract 100,000 spectators. In the 2018 Jakarta-Palembang Asian Games, e-Sports was adopted as a demonstration sport, and six events including StarCraft II and League of Legends were held and became popular. In particular, as Korean players won medals in the League of Legends, they received more attention. In recent years, not only the younger generation, but also adults, investors, and large corporations have become interested, and sports experts are also interested in e-sports as a sport suitable for the era of the 4th industrial revolution by applying convergence such as science, technology and culture. In particular, interest in online sports has increased due to the recent impact of COVID-19 virus, and people's desire for safety will remain even after the corona is subdued, and interest in online sports is also expected to gradually increase.

"E-Sport is considered a form of sport that has a close relationship with media and large corporations like baseball and soccer, but involves limited physical activity. It differs from general sports that is made through mutual exchange[4]."

According to Choi Jeong-ho and Lee Je-wook, these e-sports have been making continuous efforts to be recognized as a formal sport by emphasizing the similarity with sports such as helping mental health

Received: February 10, 2021; $1^{\text {st }}$ Review Result: March 29, 2021; $2^{\text {nd }}$ Review Result: May 18, 2021 Accepted: June 30, 2021 
and physical exercise through movements such as mouse manipulation[5]. However, there are many cases in which sports experts argue that e-Sports is difficult to be recognized as a sport because the use of large muscles is less than physical activity[5-7]. However, the possibility of adopting formal sports event, such as e-Sports, cannot be ruled out being adopted as a demonstration event in the Jakarta Palambang Asian Games[5].

Although these studies on e-sports are increasing in recent years, they are relatively small compared to the growth rate of e-sports [8-10]. In particular, there are very few studies on the perception of e-sports by college students, and in particular, there are few studies on e-sports by students majoring in sports that will play a role in future sports. Recently, researches targeting college students are increasing, because college students will lead our future society[11]. Therefore, it is important to check the opinions of college students. In particular, since there is controversy about whether e-sports is a sport or not, it is helpful to find out the perception of a sports-related major.

"Therefore, this study is aimed to (1) investigate the experiences and perceptions of e-sports among college students majoring in sports, and to find out their correlation, (2) understand the need for e-sports stadium facilities related to sports majors with basic knowledge about sports."

\section{Theoretical Background and Literature Review}

The term e-sports (eletronic sport) began in 2000, but e-sports was considered to be from 1990 to 2005[12]. The representative of e-sports in this period is Internet-based StarCraft. In the early days, esports was used as a leisure activity in the sense of utilizing game contents to create a healthy game use culture (Korea Creative Content Agency, 1999), but in 2004, 'e-Sports Development Policy Vision Declaration Ceremony' was defined as a game-based competition and activity. As a result (Ministry of Culture and Tourism, 2004), the concept was changed to a way that a person played a game instead of a person playing a computer, i.e., a person playing a computer. In terms of expansion into competitions, PGL (Professional Gamers League) and CPL (Cyberathletic Professional League) were also held in the United States and Europe, focusing on parties having their own computers in one place. Since then, the World Cyber Games (WCG), led by Korea, became an opportunity to expand into a national competition. According to the Korea Creative Content Agency (2018), the domestic e-sports market was close to 100 billion won as of 2017, and 86 competitions were held in Korea in 2017[13]. Nevertheless, stadiums with grandstands are very scarce. Therefore, if you calculate the number of spectators and the number of stadiums compared to the number of games, it can be said that games are held almost every day for a year.

There were few e-sports-related studies in the past, but they have begun to be conducted relatively actively recently. Seung-Hoon Lee (2019) analyzed the research trends related to e-sports in Korea, and targeted 42 papers published in domestic journals since 2012[14]. After setting the criteria for analysis, a list was made and three experts were consulted. Looking at the results of major studies, the first was the disparity in the academic field. Research in the field of marketing was dominated, and there were relatively many studies in the field of psychology and philosophy. In other words, there have been many studies on psychological changes through participation in e-sports. On the other hand, not much research has been done in other areas. In addition, there was an imbalance in the subject and method of the study, most of which were targeting visitors. Therefore, this study, which aims to investigate the experiences and perceptions of e-sports and to understand the facility-related needs of e-sports stadiums, is considered meaningful for university students majoring in sports that have not been targeted so far.

One of the things that should be prioritized in e-sports related research is to clarify the concept, and Hak-joon Lee and Young-sun Kim (2020) logically criticized the claim that'e-sports is not a sport' in order to justify the claim that e-sports is a sport[15]. The justification of the proposition'e-sports is not a sport' is as follows. For example, in order to argue that e-sports is not a sport because it is harmful to 
health, e-sports are viewed in the concept of transitional health, and this has contributed to mental and social health.

As a study on e-sports targeting college students, there is a study by Han-sik Moon and Seong-ho Lim (2009)[16]. In this study, 282 students enrolled in a four-year college were enrolled in order to find out the effect of college students' participation in e-sports games on their leisure satisfaction. The main results showed that male students had higher participation in e-sports games and satisfaction in leisure than female students, and the group who participated in e-sports games had higher satisfaction than the group that did not participate.

There were very few studies on e-sports stadiums. Although the stadium is slightly different depending on the nature of the competition, in general, computers, consoles, and network equipment or broadcasting equipment should be equipped. In addition to this, the main stage, screen, spectator seats, and booths for the game are needed. In addition to these basic facilities, there may be various demands. Jae-young Son (2019) conducted a study on permanent e-sports stadiums to be built in Busan, Gwangju, and Daejeon, and investigated the importance of the servicescape factors of the permanent e-sports stadium facilities[17]. In the main results of the study, the importance of entertainment and comfort was high, and the importance of screen size and quality, and the comfort of auxiliary facilities and seats was high. It was considered meaningful because of the identified priorities in e-sports stadium and was provided priorities for budget execution

\section{Method}

This study targeted 74 students majoring in sports at a university located in Gangwon-do. The purpose of targeting students majoring in sports was to find out if they perceive e-Sports as a form of sports. In addition, the reason for examining the perceptions of students about the need for sports stadiums was in the preliminary survey for this study. Students felt more familiar with sports stadiums than those related to e-sports and were able to respond without specialized knowledge about e-sports.

According to [Table 1], it can be seen that $91.9 \%$ of people have experienced e-sports-related games, and $83.8 \%$ have experience watching game-related broadcasts. The number of games was three times a weel at the most, and the first game started with $66.2 \%$ participants in elementary schools.

For the questionnaire to find out the needs and perceptions, the questionnaire developed by [9] and [10] were partially revised and several questions were added. For the experience and perception of esports, part of the questionnaire was used[9]. The questionnaire[10] was revised and used for the facility related requirements of e-sports stadiums. Most of the questions other than the subject information were answered using a five-point Likert scale.

[Table 1] Subject Information

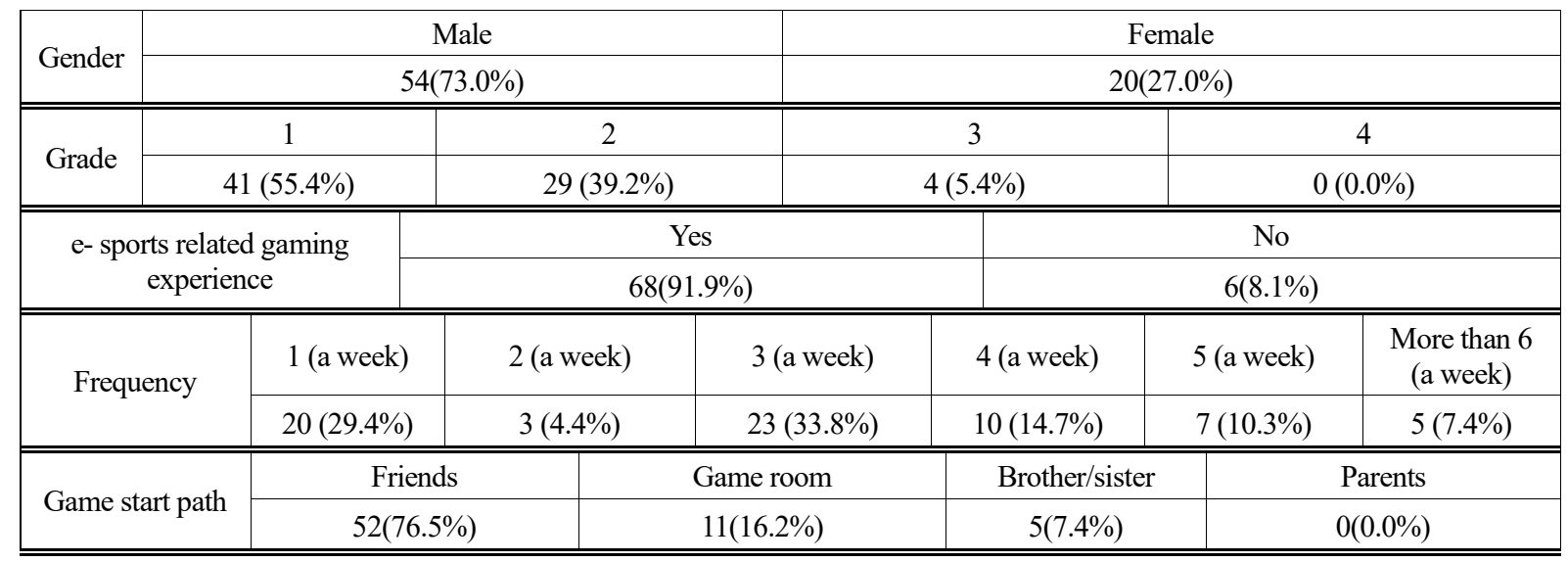




\begin{tabular}{|c|c|c|c|c|c|c|c|c|}
\hline \multirow{2}{*}{ When to start } & $\begin{array}{c}\text { Pre- } \\
\text { kindergarten }\end{array}$ & Kindergarten & $\begin{array}{c}\text { Elementary } \\
\text { school }\end{array}$ & \multicolumn{2}{|c|}{$\begin{array}{l}\text { Junior high } \\
\text { school }\end{array}$} & \multicolumn{2}{|c|}{ High school } & University \\
\hline & $0(0.0 \%)$ & $\begin{array}{c}5 \\
(7.4 \%) \\
\end{array}$ & $\begin{array}{c}45 \\
(66.2 \%) \\
\end{array}$ & $\begin{array}{r}16 \\
(23.5 \% \\
\end{array}$ & & \multicolumn{2}{|c|}{$\begin{array}{c}2 \\
(2.9 \%) \\
\end{array}$} & $\begin{array}{c}0 \\
(0.0 \%) \\
\end{array}$ \\
\hline \multirow{2}{*}{$\begin{array}{l}\text { Whether to } \\
\text { watch the } \\
\text { broadcast }\end{array}$} & \multicolumn{3}{|c|}{ Yes } & \multicolumn{5}{|c|}{ No } \\
\hline & \multicolumn{3}{|c|}{$57(83.8 \%)$} & \multicolumn{5}{|c|}{$11(16.2 \%)$} \\
\hline \multirow{2}{*}{$\begin{array}{l}\text { Freuquency of } \\
\text { Broadcast watch }\end{array}$} & 1 (a week) & 2 (a week) & 3 (a week) & 4 (a week) & & a week) & Mor & than 6 (a week) \\
\hline & $\begin{array}{c}34 \\
(59.6 \%)\end{array}$ & $\begin{array}{c}8 \\
(12.3 \%)\end{array}$ & $\begin{array}{c}4 \\
(7.0 \%)\end{array}$ & $\begin{array}{c}6 \\
(10.5 \%)\end{array}$ & & $\begin{array}{c}0 \\
0.0 \%)\end{array}$ & & $\begin{array}{c}6 \\
(10.5 \%)\end{array}$ \\
\hline
\end{tabular}

\section{Results and Discussion}

\section{1 e-Sports Perception and Correlation}

[Table 2] shows the results of the perception of e-Sports by university students majoring in sports. The highest average was the item on the prospect of e-sports, followed by interest in e-sports. In the case of questions related to 'e-sports and general sports', the average was 3.38, and the reason for thinking that e-sports and general sports are related is that competition, victory, teamwork, spontaneity, strategy, and fair play are necessary. They were mostly opinions, and the reason for not being related is that e-sports mostly involve brain activity, whereas general sports mostly involve physical activity, and e-sports are not recognized as general sports. The opinion that the effect on health was small was dominant. In the case of 'I want to engage in e-sports related work', the average was 2.64, showing the lowest average. Based on these results, sports major students believe that the prospects for e-sports are bright, and they are interested, but they do not have many thoughts of linking with general sports, taking courses, or engaging in related occupations. It seems that it would be unreasonable to open a course.

[Table 2] Perception of e-sports

\begin{tabular}{|c|c|c|}
\hline & Mean & std. \\
\hline I think e-sports has a bright outlook. & 3.89 & 1.028 \\
\hline I am interested in esports. & 3.41 & 1.134 \\
\hline eSports is related to general sports. & 3.38 & 1.036 \\
\hline I hope that e-sports related courses will be opened. & 3.31 & 1.084 \\
\hline I have a desire to take e-sports related subjects. & 3.19 & 1.131 \\
\hline I have a desire to engage in e-sports related work. & 2.64 & 1.028 \\
\hline
\end{tabular}

\begin{tabular}{|c|c|c|c|c|c|}
\hline & $\begin{array}{c}\text { Not at all } \\
1\end{array}$ & 2 & 3 & 4 & $\begin{array}{c}\text { Very much } \\
5\end{array}$ \\
\hline I am interested in e-sports. & $6(8.1 \%)$ & $7(9.5 \%)$ & $25(33.8 \%)$ & $23(31.1 \%)$ & $13(17.6 \%)$ \\
\hline $\begin{array}{c}\text { I think e-sports has a bright } \\
\text { outlook }\end{array}$ & $4(2.7 \%)$ & $2(2.7 \%)$ & $13(17.6 \%)$ & $34(45.9 \%)$ & $21(28.4 \%)$ \\
\hline $\begin{array}{c}\text { e-Sports is related to general } \\
\text { sports. }\end{array}$ & $11(14.9 \%)$ & $21(28.4 \%)$ & $29(38.2 \%)$ & $10(13.5 \%)$ & $3(4.1 \%)$ \\
\hline $\begin{array}{c}\text { I hope that e-sports related } \\
\text { courses will be opened. }\end{array}$ & $9(12.2 \%)$ & $7(9.5 \%)$ & $26(35.1 \%)$ & $25(33.8 \%)$ & $7(9.5 \%)$ \\
\hline $\begin{array}{c}\text { I have a desire to take e-sports } \\
\text { related subjects. }\end{array}$ & $6(8.1 \%)$ & $9(12.2 \%)$ & $23(31.1 \%)$ & $28(37.8 \%)$ & $8(10.8 \%)$ \\
\hline $\begin{array}{c}\text { I have a desire to engage in e- } \\
\text { sports related work. }\end{array}$ & $5(6.8 \%)$ & $7(9.5 \%)$ & $24(32.4 \%)$ & $29(39.2 \%)$ & $8(10.8 \%)$ \\
\hline
\end{tabular}


[Table 3] shows the correlation between the perception of e-sports and personal information such as game experience, number of times, and start time, and the relationship between perceptions of e-sports. There was a significant positive correlation between interest in e-sports, game experience, frequency, whether or not to watch broadcasts, and the number of views. There was also a significant correlation between the prospect of e-sports and the number of games, whether or not to watch the broadcast, and the number of times, and there was also a significant correlation with the degree of wanting to engage in e-sports related work and game experience. There were significant positive correlations with the willingness and demand to take e-sports related courses, the number of game experiences, and the number of times the broadcast was viewed.

[Table 3] Correlation Analysis

\begin{tabular}{|c|c|c|c|c|c|c|}
\hline & $\begin{array}{c}\text { I am interested in } \\
\text { e-sports. }\end{array}$ & $\begin{array}{l}\text { I think e-sports has } \\
\text { a bright outlook. }\end{array}$ & $\begin{array}{c}\text { I have a desire to } \\
\text { engage in e-sports } \\
\text { related work. }\end{array}$ & $\begin{array}{c}\text { I have a desire to } \\
\text { take a course } \\
\text { related to e-sports. }\end{array}$ & $\begin{array}{c}\text { I hope that e-sports } \\
\text { related courses } \\
\text { will be opened. }\end{array}$ & $\begin{array}{c}\text { I think e-sports is } \\
\text { related to general } \\
\text { sports. }\end{array}$ \\
\hline \multirow{2}{*}{$\begin{array}{l}\text { Gaming } \\
\text { experience }\end{array}$} & .459 & .211 & .233 & .270 & .270 & .209 \\
\hline & $.000^{* *}$ & .071 & $.045^{*}$ & $.020 *$ & $.020^{*}$ & .077 \\
\hline \multirow{2}{*}{$\begin{array}{l}\text { Freuquency of } \\
\text { games }\end{array}$} & .510 & .369 & .212 & .353 & .362 & .198 \\
\hline & $.000 * *$ & $.002 * *$ & .083 & $.003 * *$ & $.002 * *$ & .108 \\
\hline \multirow{2}{*}{$\begin{array}{l}\text { Game start } \\
\text { path }\end{array}$} & -.090 & -.029 & .077 & .025 & .039 & .039 \\
\hline & .467 & .816 & .535 & .838 & .749 & .754 \\
\hline \multirow{2}{*}{$\begin{array}{l}\text { When to start } \\
\text { the game }\end{array}$} & -.009 & .122 & .010 & -.091 & .094 & .126 \\
\hline & .942 & .322 & .937 & .458 & .447 & .310 \\
\hline \multirow{2}{*}{$\begin{array}{l}\text { Whether to } \\
\text { watch the } \\
\text { broadcast }\end{array}$} & .241 & .285 & .227 & .185 & .208 & .227 \\
\hline & $.048^{*}$ & $.019 *$ & .063 & .131 & .089 & .065 \\
\hline \multirow{2}{*}{$\begin{array}{c}\text { Freuquency of } \\
\text { Broadcast } \\
\text { watch }\end{array}$} & .352 & .340 & .230 & .280 & .298 & .112 \\
\hline & $.007 * *$ & $.010^{* *}$ & .085 & $.035^{*}$ & $.024^{*}$ & .406 \\
\hline
\end{tabular}

\begin{tabular}{|c|c|c|c|c|c|c|}
\hline & $\begin{array}{c}\text { I am interested in } \\
\text { e-sports. }\end{array}$ & $\begin{array}{l}\text { I think e-sports has } \\
\text { a bright outlook. }\end{array}$ & $\begin{array}{c}\text { I have a desire to } \\
\text { engage in e-sports } \\
\text { related work. }\end{array}$ & $\begin{array}{c}\text { I have a desire to } \\
\text { take a course } \\
\text { related to e-sports. }\end{array}$ & $\begin{array}{l}\text { I hope that e-sports } \\
\text { related courses } \\
\text { will be opened. }\end{array}$ & $\begin{array}{c}\text { I think e-sports is } \\
\text { related to general } \\
\text { sports. }\end{array}$ \\
\hline \multirow{2}{*}{ Interest } & 1 & .614 & .375 & .420 & .442 & .417 \\
\hline & & $.000 * *$ & $.001 * *$ & $.000 * *$ & $.000 * *$ & $.000 * *$ \\
\hline \multirow{2}{*}{ Otlook } & .614 & 1 & .403 & .289 & .350 & .283 \\
\hline & $.000 * *$ & & $.000 * *$ & $.013 *$ & $.002 * *$ & $.015^{*}$ \\
\hline \multirow{2}{*}{ Rlated work } & .375 & .403 & 1 & .602 & .582 & .458 \\
\hline & $.001 * *$ & $.000 * *$ & & $.000 * *$ & $.000 * *$ & $.000 * *$ \\
\hline \multirow{2}{*}{$\begin{array}{l}\text { A course related } \\
\text { to e-sports }\end{array}$} & .420 & .289 & .602 & 1 & .845 & .490 \\
\hline & $.000 * *$ & $.013 *$ & $.000 * *$ & & $.000 * *$ & $.000 * *$ \\
\hline \multirow{2}{*}{$\begin{array}{l}\text { Courses will be } \\
\text { opened }\end{array}$} & .442 & .350 & .582 & .845 & 1 & .530 \\
\hline & $.000 * *$ & $.002 * *$ & $.000 * *$ & $.000 * *$ & & $.000^{* *}$ \\
\hline \multirow{2}{*}{$\begin{array}{l}\text { Related to } \\
\text { general sports }\end{array}$} & .417 & .283 & .458 & .490 & .530 & 1 \\
\hline & $.000 * *$ & $.015^{*}$ & $.000 * *$ & $.000 * *$ & $.000 * *$ & \\
\hline
\end{tabular}

In the case of the correlation between perceptions of e-sports, interest in e-sports is positive with all items such as prospects, willingness to engage in related work, willingness and demand to take related courses, and awareness of the connection between e-sports and general sports. There was a significant correlation, and in particular, interest and prospect showed a high correlation of .614. In addition to this, there were significant correlations among the prospects, willingness to engage in related work, willingness and demand to take related courses, and perceptions of the relationship between e-sports and general sports. It was found that the more positive awareness of e-sports, such as interests and 
prospects, there is, the more the willingness to engage in related work, the willingness and demand to take related courses, and the increase in relationship between e-sports and general sports. Therefore, it is necessary to think about a way to combine the positive parts instead of highlighting only the negative parts about eSports.

[Table 4] shows the results of the t-test to see the difference in perception depending on whether or not you have played e-sports. When looking at the result of the $t$ test, similar to the correlation result, it can be seen that most of the items have positive perceptions when playing e-sports.

[Table 4] Results of the t-test (e-Sports Perception)

\begin{tabular}{|c|c|c|cc|}
\hline & $\mathrm{F}$ & $\mathrm{t}$ & $\mathrm{df}$ & $\mathrm{sig}$ \\
\hline I am interested in e-sports.. & .593 & 4.380 & 72 & .000 \\
\hline I think e-sports has a bright outlook & 9.038 & 1.832 & 72 & .071 \\
\hline e-Sports is related to general sports. & 1.165 & 2.035 & 72 & .045 \\
\hline I hope that e-sports related courses will be opened. & .035 & 2.383 & 72 & .020 \\
\hline I have a desire to take e-sports related subjects. & .346 & 2.375 & 72 & .020 \\
\hline I have a desire to engage in e-sports related work. & .049 & 1.797 & 71 & .077 \\
\hline
\end{tabular}

[Table 5] shows the results of the ANOVA test to find out whether there is a significant difference in the number of games or the recognition of e-sports. As a result, it was found that the number of games affects not only interest in e-sports, but also the prospects and the degree to which you want related classes.

[Table 5] Results of the ANOVA test

\begin{tabular}{|c|c|c|}
\hline & F & sig. \\
\hline I am interested in e-sports. & 5.391 & .000 \\
\hline I think e-sports has a bright outlook & 3.145 & .014 \\
\hline e-Sports is related to general sports. & .658 & .657 \\
\hline I hope that e-sports related courses will be opened. & 2.533 & .038 \\
\hline I have a desire to take e-sports related subjects. & 2.843 & .022 \\
\hline I have a desire to engage in e-sports related work. & .749 & .590 \\
\hline
\end{tabular}

\section{2 e-sports Stadium Facility-related Requirements}

[Table 6] shows the demand for the stadium for e-sports, and it was found that the demands for the degree of visibility of the stadium from the seats and the size of the billboard were the largest at 4.22 and 4.11, respectively. In the case of the electronic board, the demands for related items such as content, location, and number were all high. In addition, overall demand for sound facilities was also high. Meanwhile, the demand for the time required to reach the stadium and the degree of traffic congestion was relatively low.

[Table 6] e-sports Stadium Facility-related Requirements

\begin{tabular}{|c|c|c|}
\hline & Mean & std. \\
\hline The stadium must be clearly visible from the seat. & 4.22 & .798 \\
\hline The size of the billboard should be appropriate. & 4.11 & .674 \\
\hline There should be no discomfort due to the sound facilities. & 4.09 & .686 \\
\hline Seats must be well arranged. & 4.08 & .697 \\
\hline The contents of the electronic board should be easily recognizable. & 4.08 & .678 \\
\hline The location of the billboard must be appropriate. & 4.07 & .689 \\
\hline
\end{tabular}




\begin{tabular}{|c|c|c|}
\hline The location of the sound system should be appropriate. & 4.07 & 689 \\
\hline The number of billboards should be sufficient. & 4.05 & .719 \\
\hline The sound of the sound system should be adequate. & 4.01 & .731 \\
\hline The aisle of the seat should be adequate and convenient when moving. & 4.00 & .776 \\
\hline The seating area should be convenient for spectating. & 3.97 & .810 \\
\hline The number of sound facilities should be sufficient. & 3.95 & .738 \\
\hline $\begin{array}{l}\text { There should be no inconvenience in using convenient facilities due to the } \\
\text { game time. }\end{array}$ & 3.88 & .810 \\
\hline $\begin{array}{l}\text { After using the stadium, you should be able to use the surrounding } \\
\text { amenities. }\end{array}$ & 3.88 & .758 \\
\hline The means of transportation to the stadium must be well established. & 3.85 & .696 \\
\hline The use of public transportation should be convenient. & 3.84 & .777 \\
\hline You should be able to find the stadium while using nearby amenities. & 3.82 & .800 \\
\hline $\begin{array}{l}\text { The distance between the stadium and surrounding amenities should be } \\
\text { close. }\end{array}$ & 3.81 & .805 \\
\hline Coming to the stadium, traffic congestion should be low. & 3.68 & .742 \\
\hline The time required to get to the stadium should be short. & 3.64 & .769 \\
\hline
\end{tabular}

\begin{tabular}{|c|c|c|c|c|c|}
\hline & $\begin{array}{c}\text { Not at all } \\
1\end{array}$ & 2 & 3 & 4 & $\begin{array}{l}\text { Very much } \\
5\end{array}$ \\
\hline $\begin{array}{l}\text { The stadium must be clearly } \\
\text { visible from the seat. }\end{array}$ & $1(1.4 \%)$ & $1(1.4 \%)$ & $16(21.6 \%)$ & $37(50.0 \%)$ & $19(25.7 \%)$ \\
\hline $\begin{array}{l}\text { The size of the billboard } \\
\text { should be appropriate. }\end{array}$ & 0 & $1(1.4 \%)$ & $12(16.2 \%)$ & $41(55.4 \%)$ & $20(27.0 \%)$ \\
\hline $\begin{array}{c}\text { There should be no discomfort } \\
\text { due to the sound facilities. }\end{array}$ & 0 & $3(4.1 \%)$ & $13(17.6 \%)$ & $39(52.7 \%)$ & $19(25.7 \%)$ \\
\hline Seats must be well arranged. & 0 & $3(4.1 \%)$ & $8(10.8 \%)$ & $33(44.6 \%)$ & $30(40.5 \%)$ \\
\hline \begin{tabular}{|c|}
$\begin{array}{c}\text { The contents of the electronic } \\
\text { board should be easily } \\
\text { recognizable. }\end{array}$ \\
\end{tabular} & 0 & $2(2.7 \%)$ & $23(31.3 \%)$ & $34(45.9 \%)$ & $15(20.3 \%)$ \\
\hline $\begin{array}{c}\text { The location of the billboard } \\
\text { must be appropriate. }\end{array}$ & 0 & $2(2.7 \%)$ & $34(45.9 \%)$ & $27(36.5 \%)$ & $11(14.9 \%)$ \\
\hline $\begin{array}{c}\text { The location of the sound } \\
\text { system should be appropriate. }\end{array}$ & 0 & $2(2.7 \%)$ & $30(40.5 \%)$ & $32(43.2 \%)$ & $10(13.5 \%)$ \\
\hline $\begin{array}{l}\text { The number of billboards } \\
\text { should be sufficient. }\end{array}$ & 0 & $(1(1.4 \%)$ & $21(28.4 \%)$ & $40(54.1 \%)$ & $12(16.2 \%)$ \\
\hline $\begin{array}{l}\text { The sound of the sound } \\
\text { system should be adequate. }\end{array}$ & 0 & $4(5.4 \%)$ & $20(27.0 \%)$ & $36(48.6 \%)$ & $14(18.9 \%)$ \\
\hline $\begin{array}{c}\text { The aisle of the seat should be } \\
\text { adequate and convenient } \\
\text { when moving. }\end{array}$ & 0 & $1(1.4 \%)$ & $23(31.1 \%)$ & $34(45.9 \%)$ & $16(21.6 \%)$ \\
\hline $\begin{array}{l}\text { The seating area should be } \\
\text { convenient for spectating. }\end{array}$ & 0 & $2(2.7 \%)$ & $25(33.8 \%)$ & $31(41.9 \%)$ & $16(21.6 \%)$ \\
\hline $\begin{array}{c}\text { The number of sound facilities } \\
\text { should be sufficient. }\end{array}$ & 0 & $3(4.1 \%)$ & $20(27.0 \%)$ & $34(45.9 \%)$ & $17(23.0 \%)$ \\
\hline $\begin{array}{c}\text { There should be no } \\
\text { inconvenience in using } \\
\text { convenient facilities due to the } \\
\text { game time. }\end{array}$ & 0 & $1(1.4 \%)$ & $16(21.6 \%)$ & $38(51.4 \%)$ & $19(25.7 \%)$ \\
\hline $\begin{array}{c}\text { After using the stadium, you } \\
\text { should be able to use the } \\
\text { surrounding amenities. }\end{array}$ & 0 & $1(1.4 \%)$ & $12(16.2 \%)$ & $42(56.8 \%)$ & $19(25.7 \%)$ \\
\hline $\begin{array}{c}\text { The means of transportation to } \\
\text { the stadium must be well } \\
\text { established. }\end{array}$ & $1(1.4 \%)$ & 0 & $16(21.6 \%)$ & $42(56.8 \%)$ & $15(20.3 \%)$ \\
\hline $\begin{array}{c}\text { The use of public } \\
\text { transportation should be } \\
\text { convenient. }\end{array}$ & 0 & $1(1.4 \%)$ & $11(14.9 \%)$ & $42(56.8 \%)$ & $20(27.0 \%)$ \\
\hline $\begin{array}{c}\text { You should be able to find the } \\
\text { stadium while using nearby } \\
\text { amenities. }\end{array}$ & 0 & $1(1.4 \%)$ & $11(14.9 \%)$ & $43(58.1 \%)$ & $19(25.7 \%)$ \\
\hline
\end{tabular}




\begin{tabular}{|c|c|c|c|c|c|}
\hline $\begin{array}{c}\text { The distance between the } \\
\text { stadium and surrounding } \\
\text { amenities should be close. }\end{array}$ & 0 & 0 & $15(20.3 \%)$ & $39(52.7 \%)$ & $20(27.0 \%)$ \\
\hline $\begin{array}{c}\text { Coming to the stadium, traffic } \\
\text { congestion should be low. }\end{array}$ & 0 & 0 & $13(17.6 \%)$ & $40(54.1 \%)$ & $21(28.4 \%)$ \\
\hline $\begin{array}{c}\text { The time required to get to the } \\
\text { stadium should be short. }\end{array}$ & 0 & 0 & $17(23.0 \%)$ & $36(48.6 \%)$ & $21(28.4 \%)$ \\
\hline
\end{tabular}

[Table 7] shows the results of t-testing to find out whether there is a significant difference in the demands of the stadium between students with experience in e-sports games and students without experience. Looking at the t-test results, it can be seen that there are no items with significant differences between students with and without e-sports game experience.

[Table 7] Results of the t-test (e-sports Stadium Facility)

\begin{tabular}{|c|c|c|c|c|}
\hline & $\mathrm{F}$ & $\mathrm{t}$ & $\mathrm{df}$ & sig \\
\hline $\begin{array}{l}\text { The stadium must be clearly visible from the } \\
\text { seat. }\end{array}$ & .000 & .438 & 72 & .663 \\
\hline $\begin{array}{l}\text { The size of the billboard should be } \\
\text { appropriate. }\end{array}$ & .072 & .907 & 72 & .368 \\
\hline $\begin{array}{l}\text { There should be no discomfort due to the } \\
\text { sound facilities. }\end{array}$ & .019 & .546 & 72 & .587 \\
\hline Seats must be well arranged. & .177 & 1.230 & 72 & .223 \\
\hline $\begin{array}{l}\text { The contents of the electronic board should } \\
\text { be easily recognizable. }\end{array}$ & .126 & .015 & 72 & .988 \\
\hline $\begin{array}{l}\text { The location of the billboard must be } \\
\text { appropriate. }\end{array}$ & .001 & -.104 & 72 & .917 \\
\hline $\begin{array}{l}\text { The location of the sound system should be } \\
\text { appropriate. }\end{array}$ & .298 & -.540 & 72 & .591 \\
\hline $\begin{array}{l}\text { The number of billboards should be } \\
\text { sufficient. }\end{array}$ & .017 & .066 & 72 & .948 \\
\hline $\begin{array}{l}\text { The sound of the sound system should be } \\
\text { adequate. }\end{array}$ & .165 & -.071 & 72 & .944 \\
\hline $\begin{array}{l}\text { The aisle of the seat should be adequate and } \\
\text { convenient when moving. }\end{array}$ & .051 & .151 & 72 & .880 \\
\hline $\begin{array}{l}\text { The seating area should be convenient for } \\
\text { spectating. }\end{array}$ & .316 & -.029 & 72 & .977 \\
\hline $\begin{array}{l}\text { The number of sound facilities should be } \\
\text { sufficient. }\end{array}$ & .053 & .665 & 72 & .508 \\
\hline $\begin{array}{l}\text { There should be no inconvenience in using } \\
\text { convenient facilities due to the game time. }\end{array}$ & .036 & .627 & 72 & .532 \\
\hline $\begin{array}{l}\text { After using the stadium, you should be able } \\
\text { to use the surrounding amenities. }\end{array}$ & .127 & .867 & 72 & .389 \\
\hline $\begin{array}{l}\text { The means of transportation to the stadium } \\
\text { must be well established. }\end{array}$ & .771 & .966 & 72 & .337 \\
\hline $\begin{array}{l}\text { The use of public transportation should be } \\
\text { convenient. }\end{array}$ & .100 & .973 & 72 & .334 \\
\hline $\begin{array}{l}\text { You should be able to find the stadium while } \\
\text { using nearby amenities. }\end{array}$ & .162 & .934 & 72 & .354 \\
\hline $\begin{array}{l}\text { The distance between the stadium and } \\
\text { surrounding amenities should be close. }\end{array}$ & .057 & .867 & 72 & .389 \\
\hline $\begin{array}{l}\text { Coming to the stadium, traffic congestion } \\
\text { should be low. }\end{array}$ & .062 & 1.043 & 72 & .301 \\
\hline $\begin{array}{l}\text { The time required to get to the stadium } \\
\text { should be short. }\end{array}$ & .003 & .782 & 72 & .437 \\
\hline
\end{tabular}




\section{Conclusion}

This study investigated the experiences and perceptions of college students majoring in sports on esports under the premise that e-sports is considered a sport. In addition, the correlation was examined and the facility-related needs of the e-sports stadium were identified. To this end, a questionnaire was conducted for students majoring in sports at a four-year university. As a result of the survey, in the case of sports majors, most of the students had experience in e-sports, and they think that the prospects for e-sports are bright, and their interests are high. On the other hand, the average of the items related to general sports, the willingness to take courses, and the desire to engage in related occupations were not high. As a result of this, there are many students who believe that there is a difference between e-sports and general sports for sports majors, and it is considered that it is unreasonable to open e-sports-related subjects for them. In particular, in the case of'I have a desire to engage in e-sports-related work', the average was low at two points, so sports majors did not consider e-sports-related careers much. Based on these results, in order for e-sports to be recognized by the public as a sport, it seems necessary to change the perception of e-sports or to promote or operate e-sports with more emphasis on sports elements. In the case of the correlation between perceptions of e-sports, interest in e-sports, prospects, willingness to engage in related work, willingness and demand to take related courses, and perceptions on the connection between e-sports and general sports are among all items. It can be seen that there is a positive and significant correlation among them.

In the case of the demand for the stadium for e-sports, the demand for the degree of visibility of the stadium from the seats and the size of the electronic signboard was the greatest, and the demand for sound facilities was generally high. Meanwhile, the demand for the time required to reach the stadium and the degree of traffic congestion was relatively low for other items. Recently, there have been attempts to utilize existing stadiums as stadiums for e-sports competitions, and these results should be considered.

This study investigated the experiences and perceptions of university students majoring in sports on e-Sports, and the facility-related needs of e-sports stadiums. In the future society, there will be changes in sports as well. Therefore, there is a need to abandon the exclusive thought that e-sports is not a sport. Rather, it is necessary to make efforts to show a greater effect by combining e-sports and general sports. There will be a need for research on what specific efforts need to be changed and what needs to be done.

\section{References}

[1] B. W. Ahn, A Study of Psychology Factors for Leisure Activity Participants: Serious Leisure, Leisure Support, Leisure Facilitation, and Leisure Satisfaction, Asia-pacific Journal of Psychology and Counseling, (2018), Vol.2, No.2, pp.187192.

[2] N. Y. Kim, S. L. Lim, The Effects of Adult Attachment on Mental Health and Physical Health Behaviors: Mediating Effect of Satisfaction of Heterosexual Relationship, Asia-pacific Journal of Psychology and Counseling, (2018), Vol.2, No.2, pp.19-24.

[3] http://www.e-sports.or.kr, May 25 (2020)

[4] T, S. Lee, J. Y. Yoo, The Effects of Integrated Training Program Utilizing e-Sports on General Students' Awareness on Disability and Special Education Teachers' Awareness on e-Sports Program, The Journal of Inclusive Education, (2014), Vol.9, No,1, pp.1-24, DOI : 10.26592/ksie.2014.9.1.1

[5] J. H, Choi, J. W. Lee, A study on the Improvement of the Ligislation for the Sports of e-sports based on VR and AR, The Journal of Sports and Entertainment Law, (2019), Vol.22, No.1, pp.109-128.

[6] B. I. Park, e-Sports Value and the Controversial Issues and Solutions for a Problem of e-Sports from a Sportive Point 
of View, Journal of Sport and Leisure Studies, (2009), Vol.36, No.1, pp.101-120, DOI : 10.51979/KSSLS.2009.05.36.101

[7] J. H. Park, A Study on the Concept of Sport, Philosophy of Movement: Journal of the Korean Society for the Philosophy of Sport, Dance \& Martial Arts, (2012), Vol.20, No.4, pp.163-175, UCI : G704-001458.2012.20.4.011

[8] H. S. Chae, S. K. Kang, An Exploratory Research on Categorizing e-Sports as One of the Sports, Journal of Korea Game Society, (2011), Vol.11, No.3, pp.85-96, https://doi.org/10.7583/JKGS.2011.11.3.085

[9] E. Y. Choi, Y. B. Jeon, An Analysis of Factors InFluencing Copyright Protection Decision-Making among Korean eSports Game Users, The Journal of the Korea Contents Association, (2014), Vol.14, No.12, pp.723-732, https://doi.org/10.5392/JKCA.2014.14.12.723

[10] K. J. Lee, The Relationship among Participation Degree of e-Sports Game and Life-Style, Korean Society for the Sociology of Sport, (2009), Vol.7, No.1, pp.51-59.

[11] Songzhan Zhang, W. Ran, The Mental Health of College Students with Left-Behind Experience, Asia-pacific Journal of Psychology and Counseling, (2020), Vol.4. No.1, pp.21-28.

[12] e-Sports Basic Philosophy and Sociocultural Values, Korea Creative Content Agency, (2010)

[13] 2018 e-sports survey, Korea Creative Content Agency, (2018)

[14] S. H. Lee, The Analysis on the Research Trend related to Korea's eSports, eSports Studies, (2019), Vol.1, No.1, pp.2837.

[15] H. J. Lee, Y. S. Kim, eSports are Sports, Philosophy of Movement : Journal of the Korean Society for the Philosophy of Sport, Dance \& Martial Arts, (2020), Vol.28, No.1, pp.19-30.

[16] H. S. Moon, S. H. Rim, The Effects of e-Sports Game Participation on Leisure Satisfaction by University Students, Korean Journal of Leisure, Recreation \& Park, (2009). Vol.33, No.2, pp.39-52, UCI : G704-001621.2009.33.2.012

[17] J. Y. Son, A Study on Priority of e-Sports Arena Servicescape Factors, The Journal of Humanities and Social Science, (2019), Vol.10, No.5, pp.131-144, DOI : 10.22143/HSS21.10.5.10 